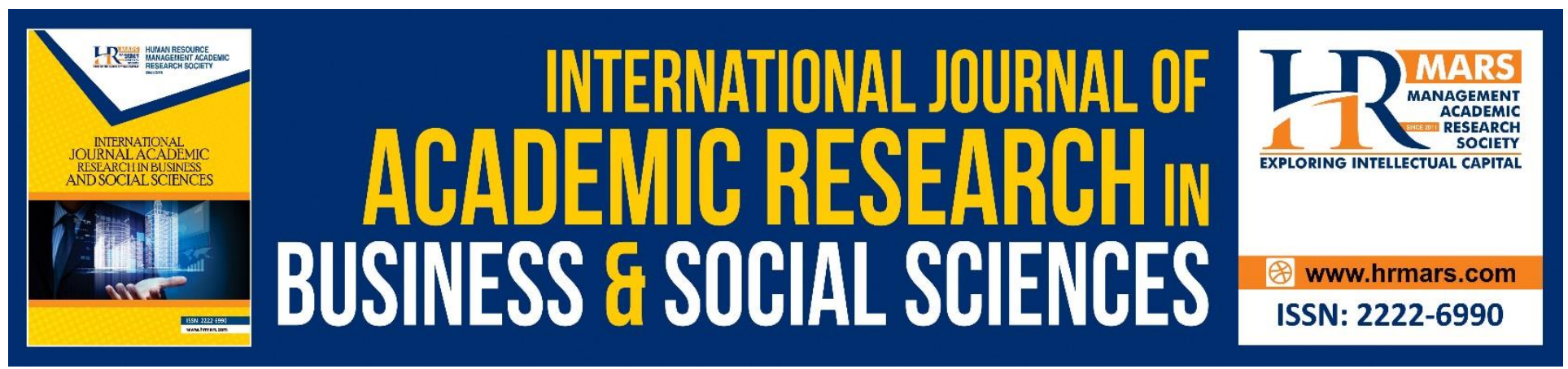

\title{
The Concept of Ta'awun in the Scientific Writing according to Al-Quran
}

Nurul Syafiqah Mazlan \& Wan Mohd Khairul Firdaus Wan Khairuldin

To Link this Article: http://dx.doi.org/10.6007/IJARBSS/v8-i11/4970

DOI: 10.6007/IJARBSS/v8-i11/4970

Received: 23 Oct 2018, Revised: 14 Nov 2018, Accepted: 30 Nov 2018

Published Online: 15 Dec 2018

In-Text Citation: (Mazlan \& Khairuldin, 2018)

To Cite this Article: Mazlan, N. S., \& Khairuldin, W. M. K. F. W. (2018). The Concept of Ta'awun in the Scientific Writing according to Al-Quran. International Journal of Academic Research in Business and Social Sciences, 8(11), 932-940.

\section{Copyright: (C) 2018 The Author(s)}

Published by Human Resource Management Academic Research Society (www.hrmars.com)

This article is published under the Creative Commons Attribution (CC BY 4.0) license. Anyone may reproduce, distribute, translate and create derivative works of this article (for both commercial and non-commercial purposes), subject to full attribution to the original publication and authors. The full terms of this license may be seen

at: http://creativecommons.org/licences/by/4.0/legalcode

Vol. 8, No. 11, 2018, Pg. 932 - 940

http://hrmars.com/index.php/pages/detail/IJARBSS

JOURNAL HOMEPAGE

Full Terms \& Conditions of access and use can be found at http://hrmars.com/index.php/pages/detail/publication-ethics 


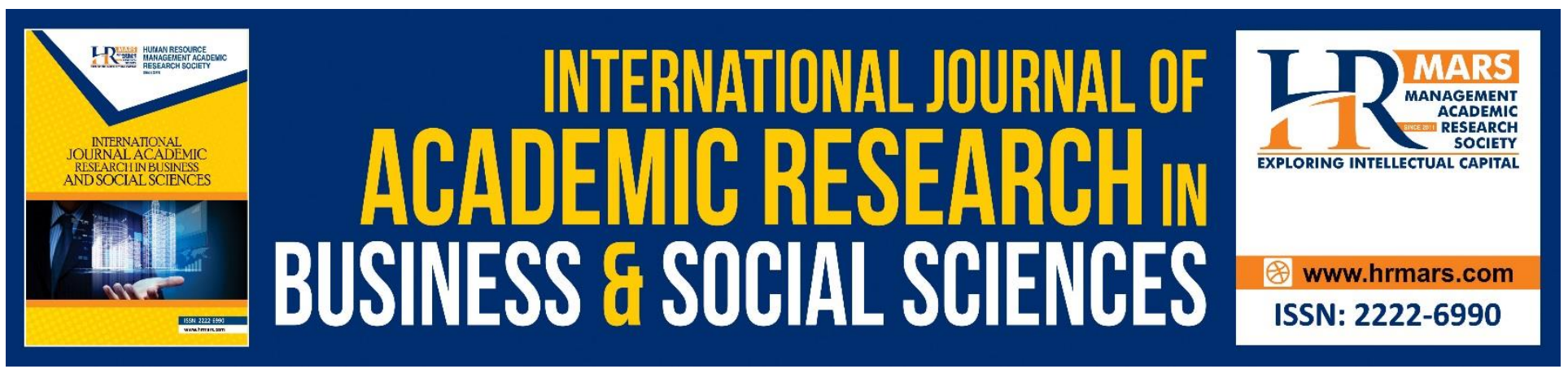

\title{
The Concept of Ta'awun in the Scientific Writing according to Al-Quran
}

\author{
Nurul Syafiqah Mazlan \& Wan Mohd Khairul Firdaus Wan Khairuldin \\ Faculty of Islamic Contemporary Studies, Universiti Sultan Zainal Abidin, \\ Terengganu. Malaysia \\ Email : wanfirdaus@unisza.edu.my
}

\begin{abstract}
Sharing of names in writing is a familiar practice today. Generally, these practices take place among academicians to meet KPI's implementation requirements. However, the extent to which the partnership is carried out in accordance with the requirements of Islam? Is the partnership just fulfilling the need to share names in writing without any guidance in line with the ta'awun concept contained in the Qur'an? This paper aims to identify the concept of ta'awun according to the view of mufassir. Furthermore, this paper aims to analyze the concept of ta'awun in scientific writing. In order to realize these goals, library research is used through data collection methods. Whereas, content analysis methods are applied in data analysis. As a result, preliminary findings indicate that sharing of name in writing is a common practice among some academics. Preliminary findings also indicate that there is a partnership that occurs without complying with the requirements of the Islamic law that leads to the opposite treatment of Quranic verses.
\end{abstract}

Keywords: Ta'awun, Sharing, Scientific Writing, Academic

\section{INTRODUCTION}

The history of writing has long begun and continues to grow up to now. This practice never ceases and is still active even though it has long been. This is because most writing guides are closely related to the books of the Qur'an since the time of Prophet Muhammad SAW and the Companions of RA. RA's friends make sure their memorization is preserved by writing on animal skins and plants ('Qattan, 2007; Rahman, 2004). The equality is the practice of writing that is still happening to date but which distinguishes it is the tool used for writing has become modern.

Prophet Muhammad, the Companions of RA and the scholars also wrote according to their respective demands or requirements. The current legacy of the writing is still being pursued by researchers among academics in conveying knowledge. Islamic religious scholars must meet the requirements of Islamic research in carrying out research or writing. 
Improved educational level can increase the demand for academic work. According to Latiff (2013), academic writing is one of the important things in making an assessment of the teaching and learning aspects. While Strongman (2014) views academic writing as an artistic performance through strategic readings and organized studies.

Academic writing also comes through sharing in writing. Sharing occurs with those directly involved in writing and contributing accordingly. Placement of names in shared copies should be accompanied by a workforce performed jointly and avoiding only some of them doing the assignment. While the other thing that differentiates is just a name. This is a violation of the true ethics of writing.

Some of them consider placing names in scientific writing without effort is one of the concepts of helping. They also consider the act as a tribute to a friend or on a friendly basis. Therefore, this paper provides an understanding of the ta'awun method as described in the Quran.

\section{RESEARCH METHODOLOGY}

This paper uses library research as a research methodology. Data collection methods have been set specifically so that the papers are more organized and systematically. To obtain data, analytical methods are used. According to Jasmi (2012), the data analysis method is the method of obtaining true and logical information from the printed material. In order to realize the objective of this paper, collecting data takes place by analyzing documents from classical sources, especially books such as Tafsir Ibn Kathir, Tafsir al-Qurtubi, Tafsir al-Azhar, Aisar al-Tafasir and Tafsir al-Sa'di. The interpretation of the tafsir is based on the author of the book which is also a mu'tabar mufassir.

After collecting the desired data, the data should be analyzed using the content analysis method. According to Krippendorff (2004) and Yusof (2004), the way in which the research is conducted in a structurally concise manner through documentary data refers to the content analysis method. Since this work data is obtained from documented data, content analysis is a suitable method for obtaining information relating to ta'awun concept in scientific writing according to the Qur'an.

\section{ANALYSIS OF THE RESEARCH}

This paper divides into two discussions. First, identify the concept of ta'awun according to the view of mufassir. Second, analyzing the concept of ta'awun in scientific writing.

Ta'awun is defined as the formation of a group to do something for mutual benefit without the need for the delivery of certain parties (Mu'jamWajiz, 1980). Whereas according to Mu'jamWasit (2004), ta'awun is mutual help. Both of these definitions show that ta'awun is referring to the helpfulness of helping to involve more than two individuals or more. 
INTERNATIONAL JOURNAL OF ACADEMIC RESEARCH IN BUSINESS AND SOCIAL SCIENCES

Vol. 8, No. 11, Nov, 2018, E-ISSN: 2222-6990 @ 2018 HRMARS

\section{The Concept of Ta'awun According to Mufassir Views}

Ta'awun atau tolong menolong adalah amalan yang perlu diamalkan dalam kehidupan seharian. Keharusan untuk melakukan amalan ini adalah berdasarkan kepada ayat suci al-Quran. Terdapat beberapa ayat dalam al-Quran yang menjelaskan mengenai konsep ta'awun. Namun, ayat dua dalam surah al-Maidah jelas menceritakan mengenai konsep ta'awun. Firman Allah SWT,

Ta'awun or help is a practice that needs to be practiced in everyday life. The necessity for doing this practice is based on the holy verses of the Qur'an. There are several verses in the Qur'an that explain the concept of ta'awun. However, verse two in surah al-Maidah clearly narrates the concept of ta'awun. Allah said:

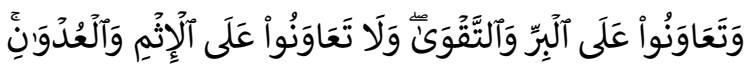

And cooperate in righteousness and piety, but do not cooperate in sin and aggression. And fear Allah ; indeed, Allah is severe in penalty.

$$
\text { (al-Maidah, 5: 2) }
$$

IbnKathir (2000), al-Qurtubi (2006). and as-Sa'di (2007), explaining the second verse of surah al-Maidah was about the command of Allah SWT to extend any form of assistance in matters of virtue and kindness. Welfare refers to behavior, inward and inwardness and to enjoy the pleasure of Allah SWT. Taqwa here means the act of avoiding all acts of ignorance and inner dislike by Allah SWT. alSa'di (2007) adds, each of the instructions of Allah SWT should be executed and every disbelief must be shunned. In order to implement such a claim, relief from people such as relatives should be involved through useful advice or physical assistance and so on.

Taqwa also covers the whole religion problem. Allah SWT instructs the believers to be devoted to Him. Allah SWT also commands to obey His command, command His Mesengger and abandon all His prohibitions. Humans should be devoted to the pleasure of Allah SWT (al-Jazairi, 2007).

In addition, Allah SWT warns and advocates for life to help in the pilgrimage in Makkah besides advocating for good behavior. Among them is such as putting parents first in every respect, respecting others and doing good to the poor and orphans (HAMKA, 1982). This shows that a variety of goodness can be done through a help-aid method.

However, at the same time, Muslims are also prohibited from providing assistance in matters that lead to disastrousness as it leads to sin. Therefore, mutual help in a partnership should be something which leads to goodness and to avoid things that lead to disadvantages (Al-Qurtubi, 2006; al-Sa'di, 2007; al-Jazairi, 2007).

The ta'awun concept also has an equality with the concept of sharing. Sharing practices are practiced in human life. It has become a habit when partnerships take place in the field of muamalat. 
Human beings are to facilitate the affairs of one another. However, sharing is not centered on the muamalat field but also in other fields including the academic field involving writing. The importance of sharing is evidenced by Quranic verses. The Qur'an is a major source for Muslims. Allah SWT says in two surahs namely an-Nisa 'and surah Saad on the importance of sharing. The Word of Allah SWT,

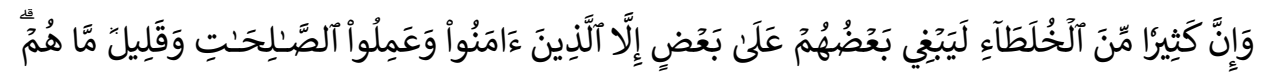

And indeed, many associates oppress one another, except for those who believe and do righteous deeds - and few are they.

(Saad, 38: 24)

According to al-Tabari (2001), the previous verse explains that the partnership takes place by mixing the property between the sharing parties. Mixing occurs so that the rights can not be distinguished from each other. Equal division is derived from the mix. This will affect sharing and persecution and tyranny in partnership. Hence, such circumstances should be avoided in order for the partnership to be profitable for all parties involved.

The Word of Allah SWT in surah al-Nisa ',

$$
\begin{aligned}
& \text { فَهُمْ شُرَكَاءُ فِي آلثُلُّثِ } \\
& \text { They share a third }
\end{aligned}
$$

The previous verse explains the heritage of inheritance among the heirs. Every beneficiary who has the right to inherit the property must have an agreement with the property (Isawi, 2009). This proves that harmful things, such as strife. This will lead to hostility between heirs. The abandoned property is not to cause harm, but to share it together.

Islam calls upon its people to do good. Sharing is one of the practices which leads to goodness as long as it meets the requirements of syarak. Partnerships based on justice and equality are urgently required to achieve mutual agreement. While partnerships that benefit only the parties or certain parties need to be avoided. Partnerships also conform to the concept of ta'awun where there is a concept of mutual help in doing something.

Based on the above discussion, a diagram is produced as a brief description of the discussion. 


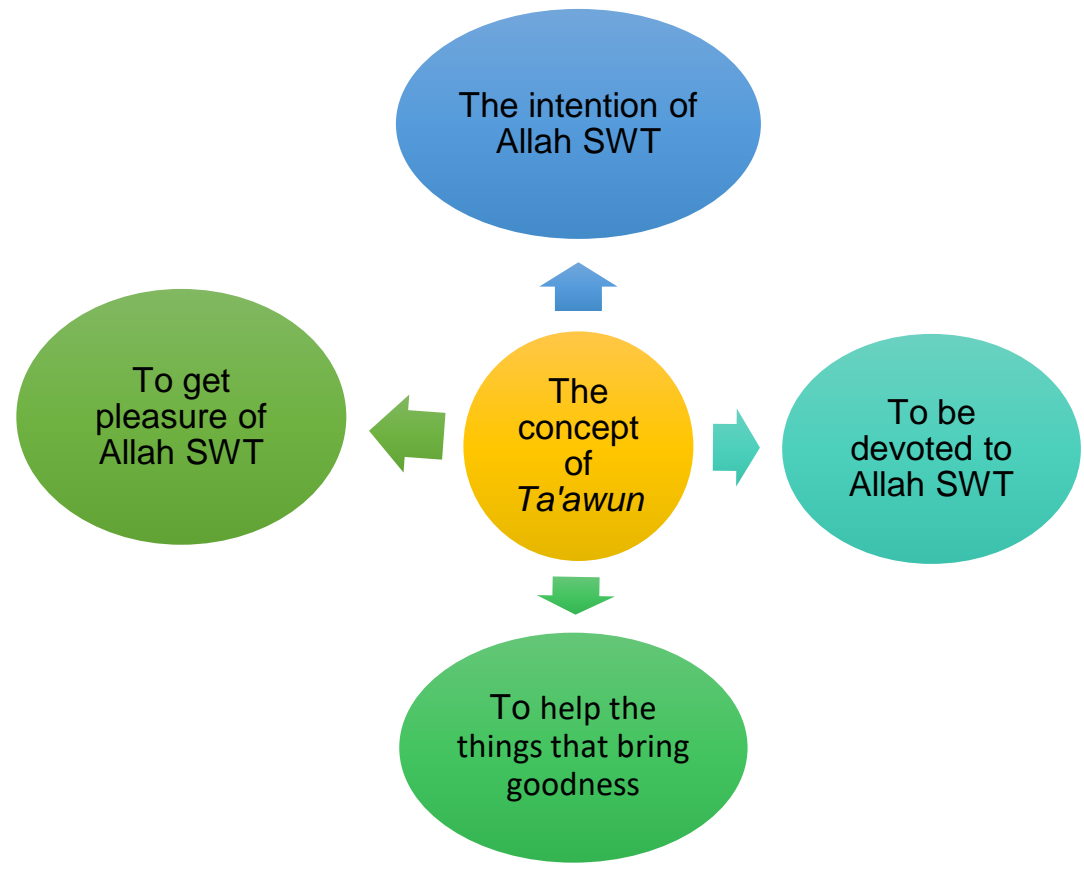

Figure 1: The concept of ta'awun in Islam

\section{DISCUSSION}

Through the concept of ta'awun according to the view of mufassir, four concepts are broken from the discussion which is the intention of Allah SWT, to get the pleasure of Allah SWT, to be devoted to Allah SWT and to help the things that bring goodness.

The first concept is the intention of Allah SWT. Every thing we do is to start with intentions. Without intentions, the only thing that is done is simply wasted because it has no specific purpose. For Muslims, the intention of doing a practice or worship must be merely because of Allah SWT. In practicing the concept of ta'awun, the intention to extend any help is because Allah is not a show of attitude.

Similarly, scientific writing must be accompanied by intentions of God. Every good writing can be produced with a good start. Writing is also sincerely done because Allah SWT rather than expect something from a human like praise. The earned praise will lift itself to be more arrogant and assume that every thing done is by selfishness rather than with the help of Allah SWT.

The second concept is to get the pleasure of Allah SWT. Something done in life is aimed at getting the pleasure of Allah SWT. When doing something must be done with great determination to get the pleasure of Allah SWT. The word will be obtained through the pleasure of Allah SWT. So, by practicing the concept of ta'awun, life's welfare can be achieved with the pleasures of Allah SWT.

Every writing done is to get the pleasure of Allah SWT. Good writing and helpfulness will be gained through such pleasures. If the writings are done to get the praise or fulfill the will of man 
INTERNATIONAL JOURNAL OF ACADEMIC RESEARCH IN BUSINESS AND SOCIAL SCIENCES Vol. 8, No. 11, Nov, 2018, E-ISSN: 2222-6990 @ 2018 HRMARS

alone, it will be against the concept of ta'awun. This conflict will invite the wrath of Allah SWT. Writing is also inviting negative things.

Furthermore, the next concept is devotion to Allah SWT. Taqwa is one of the praiseworthy attitudes that must exist in every individual. Doing good behavior is also a way of showing obedience to Allah SWT. Good behavior by extending help can increase taqwa to Allah SWT.

The taqwa to Allah SWT is also important in doing something. When the nature of taqwa exists in itself, all the bad things can be avoided. Taqwa is like a fortress that can withstand the bad things happening in writing like stealing someone else's work without his knowledge, fraudulent writings and so on that can undermine one's moral values.

The ultimate concept is to help in what matters to the good. Every good done is rewarded for him, as well as the badness done will be rewarded with his behavior. Help the good not only to get the pleasure of Allah SWT and to increase the taqwa in self but also to ease the burden of the people who really need it.

Scientific writing is a form of writing that has great value and benefits to authors and readers. For scientific writing, someone who helps another friend needs to focus on good results. If it helps to do something that does not bring goodness to syarak, it does not count in the form of goodness even if he does good to the person. For example, in the event of promotion with the help of others, not with his business is contrary to the requirements of Islam.

Hence, these four concepts explain the importance of ta'awun concept in Islam. The concept can also be practiced in scientific writing to produce good writing in parallel with Islamic law. Good writing can make something useful not just for writing but also for the community as well as the opportunity to benefit from it. Here is a table for a brief description of the relationship between ta'awun concept and scientific writing.

\begin{tabular}{|c|l|l|}
\hline Bil. & \multicolumn{1}{|c|}{$\begin{array}{c}\text { The concept of } \\
\text { Ta'awun }\end{array}$} & \multicolumn{1}{c|}{ Scientific Writing } \\
\hline 1. & $\begin{array}{l}\text { The intention of Allah } \\
\text { SWT }\end{array}$ & $\begin{array}{l}\text { Intention for Allah SWT and do not expect anything from } \\
\text { man. }\end{array}$ \\
\hline 2. & $\begin{array}{l}\text { To get pleasure of } \\
\text { Allah SWT }\end{array}$ & $\begin{array}{l}\text { Every writing done must be done to get the pleasure of Allah } \\
\text { SWT instead of praise or compulsion from man. }\end{array}$ \\
\hline 3. & $\begin{array}{l}\text { To be devoted to Allah } \\
\text { SWT }\end{array}$ & $\begin{array}{l}\text { Good writing can be produced when one has the attributes of } \\
\text { taqwa to Allah. This behavior can prevent the negative things } \\
\text { happening in writing. }\end{array}$ \\
\hline 4. & $\begin{array}{l}\text { To help the thing that } \\
\text { bring goodness }\end{array}$ & $\begin{array}{l}\text { For scientific writing, in helping others have to look at the } \\
\text { virtues that are therein and not against the will of syarak. }\end{array}$ \\
\hline
\end{tabular}

Table 1: The relationship between ta'awun concept and scientific writing 
INTERNATIONAL JOURNAL OF ACADEMIC RESEARCH IN BUSINESS AND SOCIAL SCIENCES

Vol. 8, No. 11, Nov, 2018, E-ISSN: 2222-6990 (C) 2018 HRMARS

\section{CONCLUSION}

In conclusion, the concept of ta'awun is to be practiced in Islam. There are Quranic verses which indicate the need to practice mutual help. Such help is required only to matters of kindness rather than the contrary to the teachings of the Quran.

In addition, scientific writing is an activity that has great benefits. The ta'awun concept can be applied in writing according to the concepts already described. This practice can benefit not only a certain individual, but can fulfill the needs of writing and the surrounding society also benefit from it as the dissemination of knowledge derived from the concept of ta'awun. Each one complements each other as the saying goes, the weight is equal, lightly carried as well.

\section{ACKNOWLEDGEMENT}

This project was funded by the Special Research Grant Scheme (SRGS) from UniSZA (UniSZA/2017/SRGS/07). We would like to thank UniSZA for the financing provided.

\section{References}

Al-Qurtubi. (2006). Al-Jami' lil Ahkam Al-Qurtubi. Beirut: Mua'asasah Al-Risalah.

HAMKA. (1982). Tafsir Al-Azhar. Indonesia: Panji Masyarakat.

Al-Sa'di, A.R. (2007). Tafsir Al-Sa'di. Terj. Muhammad Iqbal. Jakarta: Darul Haq.

Al-Jazairi, J. (2007). Tafsir Al-Aisar. Jakarta: Darus Sunnah Press.

Al-Tabari, M.J. (2001). Tafsir al-Tabari jami' al-bayan 'an ta'wil ay al-Quran. Beirut: Dar Ihya al-Turath al-'Arabi.

Abbas, H. (2013). Ethical Theories in Islam. New Delhi: Random Publications.

Hayland, K. (2002). Authority and invisibility: Autoral indentity in academic writing. Journal of pragmatics, 34(8), 1091-1112.

IbnKathir, I. (2000). Tafsir Ibn Kathir. Riyadh: Dar al-Salam.

Jasmi, K. (2012). Penyelidikan Kualitatif Dalam Sains Sosial. Johor Bharu: Universiti Teknologi Malaysia.

Krippendorff, K. (2004). Content Analysis: An Introduction to Its Methodology. California. SAGE Publications Ltd. .

Khairuldin, W.M.K.F.W. (2010), Metode Fatwa Sheikh 'Ali Jumaa'ah dalam Kitab al-Kalim al-TayyibFatawa 'Asriyyah. Unpublished Master Thesis. University of Malaya.

Khairuldin, W.M.K.F.W. (2016), Konsep Fatwa dalam Islam. Kuala Terengganu: Penerbit Universiti Sultan Zainal Abidin.

Khairuldin, W. M. K. F. W., Embong, A. H., Anas, W.N.I.W.N., Mohd, H. \& Ismail, D. (2018). The Application of Technology in the Dissemination of Fatwas: A Study on Religious Institutions in Malaysia, International Journal of Civil Engineering and Technology, 9(7), 2018, pp. 15901596.

Qattan, M. (2007). Mabahith fi Ulum al-Quran. Kaherah: Maktabah Wahbah.

Rahman, M.M.A. (2004). Sejarah Penulisan dan Pembukuan Hadith. Jurnal Usuluddin, 19, 115-138. Isawi, M.A. (2009). Tafsir Ibnu Mas'ud. Terj. Ali Murtadho Syahudi. Jakarta: Pustaka Azzam. 
Isawi, M.A. (2009). Tafsir Ibnu Mas'ud. Terj. Ali Murtadho Syahudi. Jakarta: Pustaka Azzam.

Salleh, M.S. (4 Julai 2011). Sindrom 'Boncengan Gratis' dalam Dunia Akademik. Utusan Malasia. Diakses daripada http:www.utusan.com.my pada 15 Julai 2018.

Yusof, R. (2004). Penyelidikan Sains Sosial. Kuala Lumpur: PTS Publications \& Distributors.

Strongman, L. (2014). Academic Writing. Cambridge Scholars Publising.

Latiff. (2013). Pengaruh Visi dan Misi Terhadap Pembentukan Dasar dan Amalan Penerbitan Unversiti: Satu Analisis. Dalam Prosiding International Conference on Social Research, ICSSR 2013. Pada 4-5 Jun, Pulau Pinang.

Mu'jam Al-Wasit. (2004). Majma Lughatul Al-'Arabiyah. Al-Maktabah Al-Syaruk Al-Dauliyah.

Mu'jam Wajiz. (1980). Majma' Al-Lughatul Al-'Arabiah. 